\title{
The Poetics of Green Esthetics: Situating Green Criticism in the Postmodern Condition
}

jan jagodzinski

Professor

Department of Secondary Education

University of Alberta

$i$ have always had the desire to rewrite evolutionary theory. $i$ once suggested this to a colleague and was laughed at; but $i$ think this is what fundamentally drives me; it defines my lack. The whole problematic surrounding "man" and the questioning of those discourses that have emerged to identify "him," which form the postmodernist background, intrigues me. This feeds a darkness, "out there," which can never be grasped. Imbedded in that darkness are issues of gender, cultural imperialism and identity. Since $i$ have always had difficulty identifying myself, this seems to be a life theme; the darkness haunts me. $i$ have troubles with borders. No one particular country can $i$ call my own. $i$ live at a point, Edmonton, both a location and a direction. $i$ don't feel particularly comfortable in education, with its continued drive towards defining "discipline" and redefining "punishment" as "reward," but neither do $i$ feel welcomed in fine arts, with its self-serving drive for "fame" and its consciousness stuck in the "studio." Where do $i$ belong? Where does anyone belong in this electronic age of ecological crisis? Where then is my site/cite/sight? When $i$ write, it seems all "disciplines" swim together. An anthropological discourse, which "grounds" the essay in this issue of Phenomenology + Pedagogy has been written. Perhaps one day it will find a home and will be made public? Until then, remain a nobody.

\section{A Global Vignette}

The prospects of living in the Greenhouse World of the 21st century are almost too horrible to contemplate. Consider the following: Gaea's ozone level continues to erode; two large holes or tears in the stratosphere have now been discovered, eliminating part of the Gaea's protective shield against the sun's deadly ultraviolet radiation; if the percentage of carbon dioxide in the atmosphere continues to increase, then by the year 2050 Gaea's annual average temperature will climb anywhere between 5-15 degrees Fahrenheit, affecting every organism on her surface; large tracts of the east and west coast of North America will be submerged under water, not so much because the glacial ice will begin to melt, but because the oceans will rise as the warm water begins to expand; presently, a species becomes extinct every 30 seconds; the great forests on her skin are dying, thousands of forest fires are visible from satellite pictures sent of the Amazon rain forest: when Gaea's population doubles in the next few decades to 8,000 million, food shortages will become an acute problem; presently, $16 \%$ of the world's population goes to bed hungry; depend-

Phenomenology + Pedagogy Volume 91991 
ing on which accounting system is used, between $50-80 \%$ of all scientific experimentation in the United States is military based. Between 80-90\% of the world's resources are used up by Japan and North America, the leaders of the capitalist spearhead. Whether one calls it new age politics (Satin, 1978), an Aquarian conspiracy (Ferguson, 1980), postmodern science (Rifkin, 1984), ecofeminism (Griffin, 1988), ecology for freedom (Bookchin, 1981), Green Peace ethics (Porritt, 1984), or ecosophy (Drengson, 1983), these responses form the strands of a global political consciousness that argues for alternate ethical, political, economic, and esthetic solutions to the domination of scientism, capitalism, and communism. The nuclear, ecological, gender, and racial issues continue to shrink spaceship Earth. Globally, the hegemony of the two superpowers is breaking up as each nation under their sway begins to find its own cultural identity. Development, progress, and standard of living are not measured in terms of GNP, indicating the material wealth a country is able to consume, rather, social values and social services are becoming the new indicators of the good (Nicaragua, for example). The United States and Japan are not held up as the progressive democratic models of leadership. Patriarchy too is under question as women become more and more conscious of their oppression, making international women's conferences possible. Globally, in terms of outright numbers, these movements are marginal. In terms of potential impact, the growing ecological myth is attempting to displace what Lyotard (1984) has termed the "grand narrative" of the West: progress, production, profit, capitalism, domination through centralization, the scale of bigness, and massive accumulation (i.e., multinationalism, nuclear power). What I have described above is certainly an alarmist view, one that is meant to shock and stun and hold the reader's attention, for the knell has been sounded, a solitary note that continues to reverberate around the entire earth. As David Suzuki called it, in a five-part series of radio broadcasts on the CBC, it's A Matter of Survival.

\section{Esthetic Ecosophy:}

\section{Playing With Green Criticism of Deep Ecology ${ }^{1}$}

It has been fashionable to be aware of semiology and deconstruction whenever culture critique is attempted. The play of signs within language has put phallocentrism to flight, cynicism becoming a common response to authority as we begin to recognize the rhetorics of representation used throughout the economy of signs. Just as physics has lost its paradigmatic status as the queen of the sciences, philosophy, as the search for Truth, has undergone a similar displacement. In a previous essay, "Toward an Ecological Aesthetic: Notes on a 'Green' Frame of Mind" (jagodzinski, 1988), I argued for the need of a new myth and the role that a particular strand of feminism played in that vision. Keeping this in mind, what follows is an attempt to steer an imaginative course between phenomenology and structuralism, ${ }^{2}$ a course that is itself overlaid by a deconstruction of the masculine and feminine positionalities. An 


\section{University of Alberta}

aesthetic ecosophy of deep ecology is proposed. This statement is a lot to unpack.

In the early 1970s Naess (1973) made a distinction between "shallow environmentalism" and "deep ecology" that has been further extended and developed by him (1984) as well as a new generation of thinkers in the 1980s, Devall and Sessions (1985), Devall $(1979,1980,1984)$, Tobias (1985), Sessions (1987). Whereas former environmental groups were anthropocentric and failed to sufficiently challenge the values of advanced industrial societies, the later movement was an attempt to level the separation between Nature and humans at the apex of creation. A "biospherical egalitarianism" or a "soft anthropometricism" has been promoted that would extend equal rights to all living things. A greater sensitivity to the degrees of encephalization, that is, to the degree that a living organism can willfully change its ecological niche, is required. Whales and porpoises, after all, have greater encephalization than, say, sharks. How human beings are to relate to each species requires our attention at the level of an ecosophy. What should be the impending harmony or equilibrium with all creatures "great and small"? Further, how can we change not only our dominance over things, but develop a sense of self that goes beyond the possessive individualism of the Enlightenment-the individual bent on having and experiencing it all? Holistic thinking and self-realization, by being locally and globally interlinked and interrelated to the Other, including the nonhuman, requires walking a path of least resistance, one that "does not tear the rice paper" as the koan states, a path that would have minimal impact on the Other's being (Snyder, 1974). It calls for a new ascetic way of life that is simple in its desire to accumulate power. To ecophize such a possibility, what I propose to develop in the following sections is to both essentialize and, at the same time, to deconstruct the language of formalist criticism as it pertains to green esthetics and green consciousness in our current historical moment. The jargon of this project is difficult to avoid. My overall intention is to present six econtological esthetic realms that interrelate us to living systems; to rewrite the familiar aesthetic language of line, color, texture, size, mass, and space in terms of deep ecology and a green poetics.

The first three dimensions relate to the local immediate environment and are associated with the oikos as the feminine pre-Oedipal levels of aesthetic experiences. ${ }^{3}$ The next three are global. These relate to the demos and are associated with the Oedipal masculine realm. Characteristically, these realms have been separate spheres, as critiqued by many feminists as the separation between nature/culture, and public/private. The values of the masculine realm have dominated the Enlightenment rhetoric and dominance over the Other. I hope green criticism is able to deconstruct this hierarchy by enacting a by now familiar ruse: to act locally and think globally. It is this imaginative global vision that projects such politics out of the realm of mere resistance. Underlying this personal vision is also 
the conviction that ethical and political ground might be formed from a green poetics. Esthetics is appealing in this sense because it appears, at first hand, ephemeral, having no bottom, an abyss. It presents the paradox of creation - from no ground to some ground, much like a Native creation myth where the muskrat, a little animal, was able to dive deep into the water after the Flood to bring up a bit of dirt to rebuild the Earth again. Criticism that oscillates between the local and the global must have a base that paradoxically floats on the water of life. The myth must tie together the material of the Humane Body with all other bodies throughout the Earth. To make the esthetic dimension a meaningful lived experience, rather than a modernist category of experience confined to the picture frame or stage, these six econtological dimensions are described as they permeate lived life. Social existence as communication with action of least resistance is always informed by one of its appearances and forms the arche-writing on the body, part of the body's recollection of being (Levin, 1985). I am suggesting, therefore, that there are at the least six levels of ethical and political ways of being green. We may operate on one or more of these levels depending on the site/cite/sight we find ourselves in. Each of these dimensions is informed by a binary opposition that is characteristically masculine and feminine. The tension of this opposition always calls on us to problematize the difficulty of life, the difficulty of choices in the historical context that we live in today. I perceive these binary oppositions, therefore, to be the extreme states of the body that inform experience (Erlebnis), holding our esthetic "skin" in dialectical tension, neither side of the opposition entirely erasing nor transcending the other, as ends and the questioning of those ends. Lived esthetic experience occurs in this dialectical gap between these binary oppositions. It is the space of play, of risk, and creativity-the poetics of green consciousness.

\section{An Esthetic Daydream: The Poetics of Green Esthetics- Three Pre-Oedipal Realms of Esthetic Experience}

The ethics and politics of line: Lived experience of directionality and the tensions of being both lost and found. The most fundamental humane experience ${ }^{4}$ is rhythm followed by movement; the spatial-temporal experience of line is continually informed by the body's negotiation between becoming lost and finding a direction. Human journeys are always packed with ambiguity, paradox, and above all surprise. It is the feeling that new vistas, new elevations, new edges are always presenting themselves as each new step is taken. Constructing an argument during a conversation, following a melody in music, creating a path through the dance of the body, all have a ground from which they began, a paradoxical point of origin that cannot be found but exists originally in chaos, in nothingness. As such all lines, all directions are traces. They are the whispers of conversations past, of memories linked together, held in a mist of relationships. Lines are segments, fragments whose ends trail off into the extremes of their own horizons. The left hand of the piano plays the 


\section{University of Alberta}

rhythm, the right the melody. The dancer begins in stillness and leaps away. Each representative instance of creative freedom (May, 1975) and intuitive exploration begins with a point and a direction.

Line is directionality. It is a crisscross informed by both the feminine and masculine presence, held in binary tension through the interaction of the horizontal and the vertical within the labyrinth of thought. Line is always hesitant, formed from the chaos of differences.

Rhythm is primordial. It is the up and down of the heartbeat, the in and out of our breathing. The dialectical binary tension of this, the first level of esthetic experience, is maintained between directionality and being lost, between intentionality and accident, between that which we can control and that which eludes our scrutiny, between blindness and insight. It is the journey of attention, of a perpetual walk toward an edge. Such heightened green consciousness is the mediation between life and death; both inform and deform the moment of movement. Only then can new ground be found and life lived.

Putting one's consciousness on the line, walking on the edge, or on a tightrope is the esthetic experience that animates us. Tightrope walkers, downhill racers, mountain climbers, car racers continually put their life on the line because at any time the human risktaking may snap. In conversation, it is only through the question that a way may be created, the journey activated, an intentional arc bridged with the Other. Yet the question may stun the body in its rhetorical force. In music, the creation of noise indicates that one has become lost, but this clamor and violence of noise points us to the very limits of our previous harmonics. It indicates the strains of human emotion and social response (Attali, 1985). Order and noise are two sides of the same coin. Mistakes, on the other hand, surprise both the player and the listener from the well-defined path. They are the lived life between tonality and atonality. The rap song of life can always be found, but this inner song, inner Klang as Kandinsky (1977) called it, can be silenced if we are led to believe that a proper musical vocabulary is necessary for its reception (McClary, 1985). For it is the tone, the tension (Latin: tonus-tension; Greek: tonus-the act of stretching) of the voice that helps to communicate our inner soul. It is the pitch-as when one throws out a message-that gives a line that must be grasped and authentically heard. Like Laurie Anderson, the cadence and timbre of such a message must consciously break the "natural" unauthentic way of hearing, what Heidegger (1962) identified as Aussage (assertion), Rede (discourse) and Gerede (idle talk). It must touch the Other's being. The singer and poet give voice (Sagen) from and to the depths of this being. Falsetto, soprano, baritone, bass, and silence, the cadence of the human voice reveals the tonality of the experiences that hide behind its calling. To have been heard means to have respected the horizon of the Other's being across a prelinguistic chasm that speaks of death, that original chaos from which the message began, before the 
wor(l)d was named. The claim of the Other is not always a soft calling; often it shrieks and withers in its agony.

The voice should maintain the oral tradition of leaders, peacemakers, prophets, and visionaries. Their voices should lead us out to dialogue. Since all conversational journeys start from a point, in the double meaning of the term-as a direction and as a starting mark-friends of the Earth must make a moral choice as to which line shall be taken. Such a choice, claimed Fromm (1981), might lead to civil disobedience for the cause of justice. The heretic must expose and unveil. Green leadership requires a conscious awareness as to the direction the journey will take. The oikoumenal good ${ }^{5}$ to be achieved must be informed by the tradition chosen. The ethics of line, of direction requires an inescapable eschatology, a philosophy of history as progress in social relationships.

The experience of line, however, may be monological rather than symbiotic, unidirectional, and univocal rather than dialogical. When one thinks of the energy transfer of the life line, the complementarity that must occur between opposites to generate life, then the telephone wire and the electric cord are analogous to Nature's umbilical cord, the root, the blood vessel; all are instances of the transference of life-the need to exchange a message across and between borders, frames, and barriers where the inside now has become the outside and the outside now has become the inside. When there is no purpose or meaning to life, one's existence becomes directionless, empty, lifeless. The borders are closed. Noise sets in. Thermic death is always possible when no breathing is allowed. Such are experiences when circumstances do not allow the risk to take place, no gasp permitted. Maps are needed, maps that allow the surveillance of the land from a safe distance. To see the lay of the land eases anxiety. It shows us where we have been, where we are going, and how we may get there. Maps freeze time and must be activated by the journey of the learning experiences. Outlines as maps are the necessary starting point. It is only when the journey is plotted with inflexibility that they become programs of repression. The computer instructed technological objectives become the antithesis of such topological map making. Such environmental programs cannot handle the strayed path. Surprise is reduced to a branching mentality, to predetermined, coded sets of choices. The primacy of straight and clean line in the Western aesthetic tradition of perspective is evident from the rationality of mechanical drawing to the straight edges of our carpentered world (Segall, Campbell, \& Herskovitz, 1966). Time and space are quantifiably stretched out through computer assisted outcomes and flow charts. The journey's esthetics are one-dimensional. The solutions to the environment are based on economics and knowledge, which are predictable and visibly testable. ${ }^{6}$ The stability of both the capitalist and communist hegemonies thrive on regularity, predeterminism, a logical and controllable future. The science of futurology ensures that five-year plans are met so that investments are secure. Line is required for being minimally 
rational but left at this functionalist state it becomes extremely boring and dull.

We must recognize that all lines are bridges to new directions. Their points must be set in motion rather than terminating in a deadly period. How should environmentalists throw out life lines to the Earth in their care? Should the bridges be different depending on the location? And if we must come to periods of rest, how do we keep such silences alive?

How, then, do we walk the earth gently? It seems we might learn something from the Aborigines and our Native populations. To cite/sight/site one instance, when an oil pipeline was to be put in the Mackenzie river valley in the Northwest Territories, the carrying capacity of the land was going to be affected. The Deni Nation hired their own anthropologist to study the land and the effects on fishing and trapping. These calculations contradicted those of the oil company's anthropologist. Justice Minister John Berger, to help settle the dispute, hired a government anthropologist. There was now a third set of figures, entirely in discord with the other two. Berger put a two-year moratorium on the decision. Today the pipe line is being built. The traditional maps of the Mackenzie territories held by the Elders will become disrupted. A whole life-style will change. The politics of line, of direction are the most difficult to determine. As a democracy, we believed that our government representatives have a direction. That direction has, since the Enlightenment, been one of economic growth, technological progress on the grounds that our GNP reflected a standard of living that corresponded with a nation's happiness. But, as the above case highlights, such is not the case. What might be other alternatives? Can we find yet other ways?

One such posture is that of responsible anarchy. ${ }^{7}$ For a politics of direction it is crucial that the point itself, the arche be questioned, otherwise line falls into nihilism and anaestheticism. Responsible anarchy is a deconstructive move for it requires both that which is found, the law of the line, and that which is lost, as the claim of the Other. Yet this is not enough, for there is a need to transgress ends, "to have ends and to be aware of those ends." Deconstruction is therefore a double gesture. The politics of line is that we do justice to that which is off line, to defend the rights of the different, not the same. To claim responsibility of the Other is also a double gesture. When the lifeline is thrown out to the claim of the Other, it is done in recognition that this claim has been excluded. It is the experience of difference, of those lost, not physically lost, but absent because they are not recognized by the Canon. The deconstruction of line between Lost and Found, Present and Absent, should make us aware of how the line is drawn in difference. Three different accounting systems for the carrying capacity of the land led to three different paths. If a path of accommodation could not be found in this maze that crossed all three lines carefully, like a river that has snaked its way around the contours of the land, then the project should have been stopped. Perhaps no other 
culture today is and was as sensitive to the ethics of line as the Australian Aborigines. Chatwin (1987) describes the "songlines" of their culture, where their entire landscape had sacred meanings, where the names of children refered to certain birthing spots, where boundaries ended when a tribe's song stopped, only to be picked up by those living in the next territory. In our postindustrial society, borders are to be policed and guarded. They have lost their magic. If such borders are weakening, their reterritorialization is on economic grounds in order to compete in a larger market, and not for symbiotic reasons to enrich life.

I remind the reader that it is from Gaea that we derive the subject of geography, the study of the lines of the Earth. Further, the study of geomacy is the divination by lines, while geology, geodesy are yet further derivatives. The grid of lines that encircle the Earth, latitudes and longitudes, were charted during imperialist expansion. Perhaps the equator still holds a certain fascination. Certain points on the globe were magic in their magnetism, but few of these points and lines are left. Certainly the mountains are there, as is the equator. Both the South and the North Poles continue to draw exploration and fascination. Yet it is above these very points that the very tears as tears in the stratosphere have been found. There is need to re-enchant the Earth, as Berman (1981) calls it. We are in dire need of a new geometry. East and West are arbitrary directions that need to be deconstructed, much as Said (1978) has done. The Mercator map has been shown to underemphasize Africa, the "dark continent," and overemphasize Europe, the "white continent," hardly surprising given the context of its making. Rarely do we realize that the racism behind color forms such representations of the Earth. The satellite pictures of Gaea were the first to decenter the naivety of maps. A new projection is badly needed. This draws me to the next esthetic-ethical dimension.

\section{The Stain of Color and The Shape of Moods}

A jump beyond living a line mentality is to consciously recognize the place of mood in our lives. A mood is like a blanket that covers us when we reflect on a conversation that has been completed. It is a recalled memory that vivifies life. What is the color of the blanket that covers Gaea today? Mood is much more than a pause. Silence, as that inward gaze, marks the time of reflection and nonparticipation in action - the listening to oneself and to the Other. Archetypically, the snake has eaten its tail-the bridge has been crossed. When the totality, paradoxically now a fragment, a period, can be reflected on, when the paragraph can be examined, then, the centering of the body between the binary opposites of unity and disunity, between harmony and disharmony, may begin. The felt tension is found in the color of a conversation. It is its musical key. Such a key will open the door to let in the color. Like Indian raga, there are many colors. Color stains the boundary of a thing. It binds the voices together. It completes their presence. It is the line turning to make a shape that 


\section{University of Alberta}

conveys a self-contained totality, a thick idea that then presents itself in a certain shade or tint, as soprano, bass, baritone. This can only happen when the journey has been completed, fulfilled, as when the artist has said "Enough! This stands on its own." This color circle occurs when children round their dance movements, when rocks are placed in a circle to form a boundary and children call it their place. When any space is bounded, as in a circus ring, a wedding ring, or a bell's ring, a centering of attention presents itself. The lived environment should also be perceived as a ring, a pitch, a place to center oneself. And periods could be colored fragments that make the day. Yet there are stains and noises on the surface of Gaea's skin, man-made oil spills, industrial pollution, forest fires.

The shape speaks the color it most easily harbors. Gold, yellow, orange, red-the embodiment of a circle gives us warmth. The shape is reflective of the voices that are allowed to speak harmoniously or in conflict. A witch's coven or a knight's round table are bound by consensual vows. The talk goes on until the spell is broken and the conversation has been rounded. Each actor "leans" and accommodates the other. Leadership becomes acephalous, a "leanership." A circle generates friends. It generates warmth and intimate exchange. The conversation becomes more than two people. It evokes voices of an ancestral past that have spoken on similar themes. The circle demands that color be more musical and fluid, not attached to the rigors of form, but released to form, its own harmonics of exchange generated. A musical key suggests a relationship between notes. It is an identification. It shows us who we are and how we are bound to others in difference occupying the same shaped space, for "the relationship of the same and the other is not level but curved. The other is both lower and higher: lower because [he/she/it] may be excluded, higher because his/her[its] exclusion cries out, calls for, claims my response" (Caputo, 1988, p. 68-69).

Personality is exposed color. The tension of the circle, the tension between the binary oppositions of hot and cold, between laughing and crying, the extremes of our body's psychological and physiological tolerance, can only be maintained by blanket spaces. The blanket has to be a security force that allows one to speak, to be exposed in a community of friends, a transitory time. This concept parallels Winnicott's (1971) discussion of blankets, dolls, and teddy bears that serve as transitional objects during a child's formative years as he or she begins to differentiate between the self and nonself while experiencing the borders of one's own being and that of others. The blanket forms a canopy, a temporary space like a tent or igloo, or the canopy of the great rain forests, so that talk might begin. It prevents the danger of shame and embarrassment that is worn on the surface of the skin. Symbols such as the crown, the hood, the tiara, the helmet suggest privileges in the conversation. Their forms are cephalous and subject to abuse. The Earth's stratosphere is also a canopy of privilege, yet there are surveillance satellites and space 
junk that mar the trust for global communication. Spying adds to the hermeneutics of suspicion. Such are the ethics of color and shape.

Western technocracy has avoided the shape of the circle and the colors of warmth, care, and security. In nature the nurturing colors of green break down and ripen into red, yellow, and blue pigments. They do not remain cool. Spiked shapes, like stars, speak of highlighting and striking out. Square shapes speak of stasis and inertia. Our patriarchal culture prefers to make the triangle and the rectangle iconic. These are shapes experienced as hierarchy and dominance. Organic shapes round the edges. They suggest softness, growth, and pregnancy. They are horizontal in their direction. They open vistas that allow the head/body to rotate a full 360 degrees. Aporias are created; a dizzy spinning that in our drunken passion may make us see through the back of our heads. Direction is then pregnant with possibility. However, centering oneself within the carpentered world of stars, squares, and rectangles always draws the eye to a point. Peripheral vision is blinkered. It is vertical in its intent. It points upward toward those on top. One's head is always lifting up or looking down. The body becomes stratified within a hierarchy of dominance. The gaze is one of surveillance.

The colors of industry and conservatism suggest the anonymity of cold calculated pursuit of the good life, the costs and benefits of Bentham's felicific calculus. It has been shown through studies of western art and literature that our sensitivity to the values of blues and violets, the dark end of the spectrum have increased since the 16th century (Huyghe, 1977). Burgundy violets and the habit noir of the 19th-century business man linger in the dark business suit and the tuxedo. Religion, too, adopts the same habit. Justice is embodied in black, sometimes red to show the gravity of the spilling of blood. Women, who were excluded until recently from the business world, were given the "privilege" to be flighty, frivolous. Color was at their disposal. But the businesswoman must also blend into the picture. Now, when hot colors appear in our culture, they do so to mock the antihumanness of our bureaucracies, like hot jazz and the punk look.

What are the ethics of color? Has color lost all sense of spiritual symbolism once had among many indigenous peoples? Has it been appropriated only in the name of power and dominance - the colors of gravity denying eros? White, the color of the most powerful racial skin, has come to symbolize the clinical mind, the germ-free, dust-free environment of high technology, the operating room, and of course the labor room.

Most of us in any large organization must remain camouflaged. Our true colors are rarely shown; they are repressed. This repression merely recapitulates the separation between private and public spaces as feminists have pointed out (Elshtain, 1981). Within intimate spaces and intimate relations we wear what we wish. The ground between lovers is cleared through fights, squabbles, and lovemaking. In large bureau- 


\section{University of Alberta}

cracies, what Goffman (1961) called "total institutions," few are high steppers. So many labor by shuffling around. What colors is our Earth undergoing? A thoughtless blending of all colors gives us a mud brown; its fragrance is not that of the living Earth, rather it has the stench of waste and decay. Does coolness and indifference by multinationals prevail? By 2005 , industrial nations have called for a $20 \%$ reduction of carbon dioxide. Every year since 1984 Mercedes Benz has violated the United States federal gas mileage standards. It has paid out $\$ 26$ million in fines, but what is money when Exxon can spend $\$ 2$ million just to run a full-page advertisement in American newspapers to cover up the environment damage of the oil spill by the Exxon Valdez. The harmony of colors as in difference, rather than as indifference, can only bring about enrichment, for the dominant colors in western tradition have always been white and gold. Racism celebrates clarity, purity-the intensity of the diamond instead of the coal, refined stones, not the common stock.

Take any area of the forest. Study the myriad shapes and colors of interconnectedness. What are the ethics of keeping it alive while recognizing its death? We are beginning to realize today that to keep life we must go to the margins to preserve it. Middle-sized frogs are dying, north and south of the equator. Niches that seem far away are affected by pollutants issuing from the centers. We need only think of acid rain and nuclear fallout to realize that there are no distances, only points, and these points are slowly changing colors, muting, fading as the "blood" is sucked out of them. Green has become symbolic of this "blood." With red as its complementary, the edge between them shimmers in revival.

\section{Texture: The Lived Experience of the Home and Familiarity}

Texture forms the third level of the esthetic dimension. Texture is the conversation with things, to enable one to know them intimately. It is the language of poetry, the adjectives and adverbs that form the ground of distinction. Texture is our personal communication with Nature's dialogue: it is the experience of craft that intimately binds our consciousness with Gaea's material consciousness ${ }^{8}$; it is the potter in conversation with clay; it is the weaver in conversation with fibre; it is the lapidary maker in conversation with stone; it is the crafts tradition that is the very fabric of technology. Texture touches. It is found within the palm of the hand and at the tips of the fingers. One cannot get closer to the Earth than through the touch of the hand. The grasp of the fingers presents an immediate response. The greatest amount of grey matter in the brain is dedicated to the hands. They play, they sensitize, they touch.

Texture is the exposed history of the thing embodied on its patina, worn like our skin. The texture of things harbors the binary opposition of home and alienation. When we know the texture of things we feel comfort, security, and belonging as when we see familiarity in the face. We must touch things in order to make them our own, participate in them to see the surfaces and their responses; otherwise the Other is always alienated 
and can never allow for the Other's difference. Appearing at a distance the Other becomes flattened, smooth, generalized, nondescript. All Blacks become alike, all Asians are lumped together, all Whites are the same. Textures cannot be known without differentiation, without felt similarities and differences throughout the body. To generate such knowledge requires worn spaces, a continual coming back to the thing so that we might make it our own-make it familiar within our famil(y)arity. It requires the traveled look. Only then can we make it a part of our biographies, something we can stand for. It gives us our character and the Other takes on character.

A home away from home suggests a cared for place. The dialectical tension between the binary opposition requires that we embrace everything we touch to make it a part of ourselves. We must avoid breaking or marking things. Historically, these appear to be signs of dominance. Repair embodies the ethics of texture, for in the art of repair there is mending, healing, and love to keep a thing's essence alive.

This is also true of ourselves. We must accept the wear marks of our own bodies, the wrinkles on our face, the withering of our hands as the body takes on a history of experiences as we proceed toward our death. Old age becomes acceptable and recognized for its dignity. This personal history, this body and this psyche, taking on signs of growth and destruction must be cared for and repaired; not unlike the baseball glove that must fit the hand or the sweater that must fit the body. These too must be restitched and refurbished to give them added meaning and comfort. Worn sweaters, old clothes possess a history, a texture of the battles, abuses, victories, and festivals the things have gone through. Antique furniture, used books, flea markets, heirlooms, handed down sacred objects of tribal life, old toys, all such things hold a history about them. In short, all tool kits are remembered by the body. Former songs bring forth a nostalgia as we are reminded of times when we were young. A certain style of a bygone era reactivates our memories and revives our youth.

Texture is therefore deconstructing our waste and decay. It is recognizing our own abjections. What we consume and dispose, both physically and mentally, allows us to grow. What we excrete from our minds and our bodies may be reused and placed in new contexts. It is through our failures that we learn who we are. Repair is nurturing and healing. All living things require nurturing and healing if their life is to be preserved. Everything new demands that it be approached with a soft instrumentalism, gently prodded and closely felt. Van Gogh knew this well. He painted with heavy texture everything he came in contact with.

Unquestionably, natural material leaves the mark of character. Leather, clay, wood, wool, and organic fibers bear the wrinkles and blemishes left on them. They possess consciousness. Plastics do not. Synthetic plastics do not take on a patina, a life. One is merely able to keep it longer and looking like new longer. The experience of texture is left for the very 


\section{University of Alberta}

rich-those who can afford to buy antiques, vintage cars and wines and purchase historical houses in need of restoration. The connoisseur, the aesthete, becomes our artistic expert in residence. Art preserves its elite status of excellence. Rather than recognizing that the dimension of lived aesthetic experience is available for all, we have relinquished our power of discrimination to those who can claim extraordinary refinement. Yet everywhere we may find signs of creative ad-hocism (Jencks, 1973), what has been demeaned as folk, primitive, and naive art is where human creativity flowers through personal solutions to psychological and physical problems. Rather than haute cuisine, home cooked meals and handed down recipes provide the identity of a distinctive style-that "little bit extra," as is often said-natural brewed beer, organic food, that family restaurant that provides a distinctive taste.

All this when compared with consumerism and fast food take-outs, shows how impoverished this dimension has become. When you slurp from a MacDonald's plastic cup, through a straw, it is a very one-dimensional experience. It becomes iconic of western functionality. You do not examine the color of the liquid you are drinking, nor would you want to for fear of being repulsed. Slurping it through a straw hardly makes the liquid linger in my mouth. Coke and Pepsi have manufactured our loss for the taste of pure water (the ramifications of this for health reasons are just too staggering to contemplate). Nor does grasping a plastic, waxed paper cup hold a pleasant experience. Japanese tea ceremonies, Viennese coffee houses, British pubs are reminiscent of what we have lost. Spaces now are meant to be occupied for a short time. Conversations are kept brief in such garish surroundings. If all this were otherwise, McDonald's and companies like it would be out of business.

Western capitalism has denied us the textural dimension of the esthetic experience. Western capitalism has generated wants rather than needs, the simulacra (Baudrillard, 1983) of the commodity. The corporate sector continues to commit the sin of gluttony. Waste is not recycled for further growth, rather a consumer mentality of needless production is propagated. The history of things is eliminated. Repair, as the nurturing back to life of a thing, is being eliminated. Built-in obsolescence is one way; throwing the thing away is another. As Jameson (1983) points out, in a postmodernist society everything is a pastiche of everything else. The self, as reflected by a well-defined artistic style, is gone. Furthermore, the self has become schizophrenic (Deleuze \& Guattari, 1983). Because history cannot be totalized, we cannot locate ourselves historically. The postmodern prophets of extremity Foucault, Lyotard, and Derrida have presented a decidedly antihumanist stance. ${ }^{9}$ Foucault's (1972) oeuvre involves the replacement of those unities of humanist thought such as tradition, influence, development, evolution, source, and origin with concepts like discontinuity, rupture, threshold, limit, and transformation. Lyotard (1984) opposes the heterogeneity of the "little narratives" to the dogmatism of the "grand narratives." He claims that such meta-narra- 
tives legitimate the scientism of the age. And with Derrida's (1974) deconstructivist turn there is a continual breakdown and play of signifiers. Our language has become soft.

\section{Three Oedipal Realms of Esthetic Experience}

\section{Size: The Lived Experience of Scale}

The question of size, of design, of theater requires that the esthetic dimension reach out to a wider audience. The question of scale becomes important. The binary oppositions between the mega and the micro, between the megalithic and the miniature inform the tension of a centered self who tries to mediate the superego through the psychological proportionality of things. This is a standing up to the Father. Both things and people, larger than Self, must be accommodated by the individual psyche. Miniatures, for example, allow for the reduction of things to a surveyable scale. Psychologically, they provide the control of structures too large for the body to handle proportionately. Miniaturization allows for the reduction of things to the level of endearment. The impulse to keep a fish tank, to practice the ancient Chinese art of feng shui (Rossbach, 1983), or the ancient Japanese art of bonsai, to collect stamps of countries around the world, to wear medallions, badges, lockets, and wrist watches, to model cars and buildings, to use coins; these are all substitutions, surrogates, and reminders of the larger institutional and personal values that they represent. They offer a form of transportable presence of the larger whole. Miniatures are engulfed by the body. Their size, where they appear on the body as ornament, and at what distance they are viewed determine their relative importance. One might think of cut precious stones as representative of the extreme care and intricacy of miniature production. One has to look at the subtlety of detail to appreciate their worth. All miniaturization is suggestive of fine tooling, fine control, flashes of brilliance, and exquisiteness. We have all experienced moments when many mirrors, many sides have been presented so that we feel a grasp of an issue.

Staged drama as theater, then, is yet another source of the body negotiating the concerns of society. The scale of this form is larger than the improvisation of ad-hocism found only at the local level, yet dramatic presentations are not as large as the special event or festival characteristic of the next layer of esthetic participation. Theater provides the exemplar through which a broader theme may emerge.

In the preindustrial world, the craftsperson provided the proportionality of things to clients as use value. Inequalities among the classes were perpetuated through such things as shoe length, materials used, and of course the time of production required. Customization rather than standardization was the measure of proportionality. Production was limited but quality prevailed. In Modern Times, to hark back to Chaplin's delightfully funny satire, we live in a mega society where the stan- 


\section{University of Alberta}

dardization of things is based on an ideal individual, a faceless individual. The ideal man, woman, child, family, in a particular age cohort, becomes the target of industrial design (Papanek, 1974). Vast sectors of the physically disabled and the aged are overlooked. Particular ethnic needs are leveled. Young army recruits become testers for many of the products designed by industry. Again, the best designed goods, like clothing, houses, cars are extremely expensive and out of reach for the general populace. Rather, the overproduction of goods that offer variations in cosmetic change of design proliferate. Research becomes advertising, selling the same thing in a different package rather than authentic product redesign for humane use or, as the old adage goes, putting the same old wine in new bottles. Designer water, like Perrier, exemplifies the irony of the age. Million-year icebergs are next to be bottled. This mega mentality of postmodernism has dwarfed the individual. We are stuffed full of overchoice. This is customization, but customization driven by the values of the market place, by innovation, not by human needs.

The ethics of size are particularly important with respect to bureaucratic dialogue. The belittlement of the other through sarcasm and ridicule, psychologically cutting down one to size, betrays the good faith of conversation and the reinforcement of domination. On the other hand, this psychological maneuver may work to the advantage of the oppressed when they can name the transgression against them, like calling authoritarian men phallocrats or making a derogatory term like "nigger" their own. Milder forms of such leveling of size and resistance occur when students call their teachers by their first names or even their nicknames or when the French and Germans drop their formal language with strangers. Tribal life also indicated psychological advantage was gained when an evil god's name was repeated over and over, each time shortening the sacred name until the god was psychologically overcome.

The redresses of power must be exercised. Difficult concepts and loaded words should be unpacked by exposing the experience that supports them. Green leaders need to exercise the virtues of humility, empowering their community so that constituents feel as equals in conversation. Humility is lost when things are blown out of proportion. Disguises are then taken on, mystification promoted, jargon presented. Leaders become pompous and proud in their display of knowledge. Historical instances are readily available. One need only think of the differences between Linear A and Linear B writing in the Egyptian context, the continuance of Latin in Catholic tradition, and the continued esoteric wording of jurisprudence as examples of discourse that isolate groups rather than enabling them to understand each other. This is the scaling of a stratified society. Each of these instances preserves the conversation in the hands of the few. Size and design are therefore important questions for justice. Understanding at this lived esthetic dimension means that any and every institution is under investigation. Satire and dystopia are able to present the truth of their perversion through an exaggeration 
of their disabling characteristics. In contrast, fantasy and utopian visions present the perversion of their enabling characteristics. Both are strong readings of future potentialities.

Perhaps no one more than Sale $(1982,1984,1985)$ and Schumacher (1973) have made us aware of the ecological necessities of scale. Sale in particular speaks of harmony in relation to scale. Prior to the rise of our postindustrial state, he notes, there was always an intuitive sense of size operating in human settlements. Archaic villages, Greek city states, medieval municipalities, New England towns and religious communities were all governed by a self-governing human unit beyond which it would not grow. Harmony through division was practiced. ${ }^{10}$ Sale applies the four determinates of civilization: scale, economy, politics, and society to the notion of bioregionalism; bioregionalism being a territory that is "naturally determined" through the attributes of flora, fauna, water, and climate soils and landforms, and the human settlements and cultures these attributes have given rise to. These boundaries are fluid and identifiable and Sale (1984) identifies them from the largest to the smallestecoregion, georegion, vitaregions. An economy of preservation, conservation, and accommodation of a steady state to reach climax would be maintained.

\section{Mass: The Lived Experience of Gravity}

Mass, as the fifth esthetic dimension, is informed through the binary oppositions of gravity (permanence) and lightness (movability). Our minds quiver from the pull of tradition and the hope of Utopia. Such quiverings are out-of-body experiences that we try to comprehend. At the level of mass we recall archetypes that lie between heaven and hell, between good and evil. Gravity means denseness and compactness. It means weighty concerns - the lure of well-trodden traditions. We are creatures of permanence. Our raison d'être is left in things that endure through time. Perhaps it is our way to push back death, to leave something of ourselves behind. It is perhaps the impulse of the funerary arts. We preserve the traces of ourselves through mummification, embalming statues and images built in effigy, yet paradoxically there is a mindfulness that we ultimately belong to Gaea.

Things of mass embody the meanings, the summation of the history of a people and a culture. They can, as in an autobiography, also embody the summation of one person, a leader. Together, they represent the sculpture, the music, the great epics, the great literature of any period. They are our civilizational archetypes, emerging as symbols of unification, binding desperate groups together. Such symbols possess power over us and are encrusted with the weight of their sacredness; they are holy. They push on our backs and propel us forward on well worn paths already travelled by our predecessors. Turned into orthodoxy, the wisdom within these texts becomes stultified, and orthodoxy and the fetishization of this 


\section{University of Alberta}

power creates domination, maintains rigidity, prevents flexibility, and maintains oppression.

The body's remembrance of mass may be extended through the corridors of time-to a moment when birth and development are continuous and nondivisible, to a place where gravity, which informs Gaea, embodies the memory of our planet (Lovelock, 1979). There is speculation in the "new science of life" (Sheldrake, 1981) that all living things are shaped by morphogenetic fields that have been formed through the discourse of past forms of a given species. Punctuated evolution occurs. New species come into existence only when that link with their past is broken and a dissipation of the structure occurs (Prigogine, 1980). The tradition or archetype that informs that species no longer serves its creation, its evolvement. Today, we as a species, homo sapiens, are undergoing a similar dissipation. Feminists have raised the issue as to whether our current archetypes are one-sided-heroic and male. Could and should other archetypes inform our species if we are to continue to live on the skin of Gaea?

All traditions are heavy. Gravity, Gaea's consciousness, pulls at them with all its might. Yet they are difficult to move, for their composition is woven with many voices and countless generations. And, unlike the insect world, where new species are discovered daily, wo(man) is unique to this Earth. History as myth, as the conscious experiences of men and women, has been one-sided. Its underside, its belly, is missing (Boulding, 1976). The history of civilization endures as male experience and is difficult to deconstruct. Like a white dwarf its gravitational pull is greater than that of the earth. Gaea is slowly dying. Perhaps only through disequilibrium can the tension of gravity be met. Certain texts like the Bible, the Torah, the Koran, are conversations that stand as monuments to the accomplishments of a male culture's history. They are the dolmens of the Axial Age (Jaspers, 1957). Yet such dolmens require constant reinterpretation, misreading to produce a reading that speaks to today's age. Their gravity must speak to myriad transcendental concerns about justice, love, and freedom. Their music must be uplifting and transvaluative. Perhaps it is time that such dolmens be stood on their heads? But to do so, one must first learn their structures to make them light enough to lift.

Works of gravity move masses: Men and women go into battle for a cause; a nation mourns the loss of a treasured leader; requiems are staged for the dead during disasters. Spiritual masses celebrate collective events. Pageants, festivals, potlatches, rituals require orchestration and duration to take place. Similarly oracles, pow wows, summit meetings require build-up and deliberation before major gravities can be dealt with. The collective tension that a group feels between the pull of permanence and the freedom of ephemerality requires that balance always be asymetrical. Such an enigma requires that permanence be continually 
challenged by the guidance of the "god" Re, a prefix that stands with diligence in our syntax. The tradition must be (re)read, (re)searched, (re)thought, (re)experienced, to make understanding of a tradition lighter, more parsimonious. Through this eternal return, the old is (mis)read, (mis)understood into the new. The introduction of the prefix Mis as the dialectical counterpoint to the prefix Re, (re)cognizes the harmony of (dis)equilibrium and (de)construction. This in itself is a paradox because the act generates the prefixes dis and de which in the English language are (pre)fixes that anticipate (de)struction rather than (re)construction of the new. Whatever appears permanent, orthodox, enduring, everlasting, parading as the gospel of the many must be (de)institutionalized, (re)duced, its structures made threadbare, the useless timbers discarded so that new meanings might emerge. Such a task requires "spiritual" guidance. The Muses must be (re)called and (re)examined, especially Mnemosyne (memory), Clio (history), and Calliope (heroic poetry). In this way no cults can be preserved. No one lives off the spirit of another's reputation. Such experiences of translation embody the very essence of economy. Mnemonics of the mind, body, and soul are required for it is the soul that harbors the collective dreams of a people. Since the Enlightenment, the soul has disappeared from metaphysical discourse. It needs to be (re)called (Hillman, 1975) within the esthetics of mass.

The struggle among giants and titans, organic intellectuals (Gramsci, 1971), heroes, heroines, and heretics, David and Goliath, legends of the Amazons, gods and goddesses, the Holocaust, Mai Lai Massacre are the archetypal symbols of cultural belief. These are the instances that embody the narratives of mass experience. In these legends are the lessons of wisdom (sophia) that are meant to be (re)vealed. Within the myths and fairytales lie the mores of a culture (Von Franz, 1978). To understand their structure is to be able to animate an entire body, to lighten any load. Such knowledge, converted to the level of practical knowledge, (phronesis) provides the new turn in the path for tradition to walk on. The wise person understands the structure of things. The wise person, the crone, the wizard, the witch, the scholar, the prophet, the author (Foucault, 1984) is able to manipulate the tradition effortlessly, move large bodies of knowledge subtly. They are like the sculptors who always work with material of the age. This material too is manipulated effortlessly, be it steel, glass, iron, stone, or ferro-concrete. Like sculpture that is displayed in the midst of our cities, or like Earth sculpture that is displayed in remote and isolated locations, such people are capable of coexisting in both places, perhaps once again (re)capitulating the paradox of permanence/movement. Physical summations of mass are presented in the forms of mathematical systems; perhaps these need to be sup(planted) with musical summations, a new coven of Muses found. Human summations have been presented as epics, philosophies, religions, which claim a path to truth, righteousness, heaven, nirvana, 


\section{University of Alberta}

(re)working the hell its creators felt born into. Today science, the latest western summation of mass, needs to be sup(planted) by a new myth.

The ethics and politics of mass suggest that sacred spaces, special places, are needed to harbor traditions if their dialogues are to be kept alive. Historically, the paleolithic caves, the Delphic oracles, the academies, the universities, the mosques, the churches have provided for the word to be read and interpreted. Characteristically, the re(interpretation) of traditions has taken place in times of crisis, and only when a critical mass was achieved did human consciousness change (Jaynes, 1976). What should be the responsibility of leaders be if they hold such power to shape a tradition? What should be the role of our organic intellectuals? Einstein and Oppenheim struggled with such questions, as did Joan of Arc. How should power be delegated? Who should conduct the new orchestration? Or should it now be understood that orchestration as a unification be changed to polyphony and cacophony - allowing many voices to be heard? Should the tradition of leadership itself be questioned? Perhaps the new polyphony is to be found within each autobiography, the entire tradition improvised through responsible anarchy.

Psychologically, the western technological imagination treats the manipulation of mass clinically, that is, ideologically. The mass is well orchestrated, manipulated through the communications media and propaganda. The power of the state comes under question. To what extent has the state given the public a voice? How has the public forum been maintained? What space has been cleared for the discussion of "sacred" knowledge as developed above which affects our very being? Is the space created by representative democracy enough? Could other forms of participatory democracy (Stravrianos, 1976) be developed? Felski (1989) has argued that the new emerging public spaces can only exist, paradoxically as networks, like Deleuzean rhizomatic structures (Bürger, 1985).

Physically, the myth of Icarus has been realized and exemplified by the technological ability to literally move mountains and touch the heavens. When we push a heavy vault door with ease, see a jumbo jet or the Challenger leave the earth, we feel a sense of magic and awe. However, the world economy is out of balance. The market price overrides any sense of use value. The stockpiling of foodstuffs, nuclear bombs, nuclear waste, the placement of our aged into nursing homes, the hoarding and cornering of the stock market, the perpetuation of unemployment so that supply and demand of labor may be controlled all indicate that technological rationality maintains that the hoarding of mass provides man with the greatest of pleasure.

The poetics of mass for green consciousness is immense. Bodies of knowledge, Foucault's articulation of discourse as traditions that answer questions of profound enigmatic human concerns, were the achievement of the humanities (Dreyfus \& Rabinow, 1982), yet it is these Imaginary 
discourses that are dissipating, breaking up. What is needed, in Castoriadis' (1984) sense, is a new social Imaginary, and this Imaginary can only be formed by the decentering vision, to the peripheries that have been left out. Mainly the New Right of orthodoxy speaks to the moral dilemma we find ourselves in. Their answers concerning the practical (ethical) life have been fashioned by a male discourse. Parochial schools, for example, have taken on the task of filling the spiritual vacuum created by the Enlightenment. The question that religion is also deeply patriarchal has hardly been touched (Daly, 1978; Fiorenza, 1985). It requires the examination of cross-cultural solutions to the universals of power, equality, peace, and death if alternatives are to be found. The ethics and politics of a mass esthetics have been stripped of this transcendent potential. Current attempts to view knowledge as a hermeneutic enterprise (Gadamer, 1975) require that it be radicalized (Caputo, 1987). All knowledge stands within a historical conversation that shapes our collective myth, and women of all persuasions are trying to take part in that conversation, to add to its gravity by lightening its current structure.

\section{Space: The Lived Experience of the Cosmos}

The final frontier? It may well be, for we are on the edge of cosmological change: the move from a male centered view that has held our attention since Einstein, to a decentered Cosmos, which becomes more and more of a possibility as the Voyager leaves our Solar System. The implications of such an upheaval have yet to take full effect, but the aporias have been reached. Theorizations that go beyond the speed of light are wanting. An absence of light? What can that possibly mean? How can the dark be "written" in? Such a question leads us again to the mystery of life and death, back to myth of a new emerging Imaginary. The dialectics between the darkness and the open eye, mediated only by the membrane of our blinking, is intriguing. It is light and vision, the central metaphors of the Enlightenment that hold us prisoners of our own mind.

The esthetic dimension of space as embodied in the architecture of a culture forms the final analysis. More than a canopy or shelter, it is an envelope that symbolizes the mythology of a culture. It forms the highest and most spiritual creative dimension. Topple the Tower of Babel and you deconstruct the sacred ground it rests on. Unearth the deified archetypes and you expose the soul of a tradition. Destroy the gods and goddesses and you destroy the very core of beliefs that both blind and bind a culture. Architecture provides the (re)newing experiences for a people. It is the place for spiritual bathing. In them one experiences the sublime, the awe, and the mystery of the universe. Stonehenge, the pyramids, mastabas, churches, synagogues, temples, and today our space science centers are such (re)newing baths into which one becomes baptized into a culture's cosmology. The architect, as the composer of unearthly music, must capture the highest aspirations, the collective unconscious imagination, and give it spiritual form. Today the global 


\section{University of Alberta}

envelope, Gaea, is emerging to compete against the current cosmology. Opposing this are the postmodern multicorporation buildings with their pastiche of styles that allude to the greatness of the past.

All of the previous aesthetic dimensions are subsumed under this collective vision. It is informed through binary oppositions of an envelope and the open air, between participation and ostracism, between the Earth and the Cosmos. Exile, both physical and psychological, is perhaps the most difficult cross to bear because it demands, not only that we struggle with the paradox of having to reject an entire tradition that bore us, but also to realize that a new forthcoming space needs to be created. Perhaps such feelings inform the explorations of the adventurer, the astronaut, the inventor, the stargazer. On their journey, they take something along to remind them of the culture they once knew. If they return, they do so with reluctance. Their mother culture is now perceived through a new body. The esthetics of space requires coming back full circle, starting the journey of line once more, perhaps hungry, shelterless, and thirsty, yet being in full knowledge that such a journey must be taken, for the current world view must be rejected, a new cosmos projected. Such are the birth pains of ideology-critique. Such are the pains and joys experienced by a Galileo or a Lilith (Phillips, 1984). Perhaps the ecological and feminist movements will provide the new cosmology for the Spaceship Earth?

Western Enlightenment has left us only with patriarchal dominance; the lived spaces of functionality speak neither to the sacred nor to the profane. They just are. The clean line aesthetic (Sachlikeit) and the vertical dominance of the skyscraper celebrate the male victory of corporate power. It is much more the male who has perceived the verticality of power. His lens searches the universe for new planets to conquer. His energies are concentrated on a multibillion dollar weapons industry and the economic exploitation of space that is out of Gaea's reach. His communication satellites are the new eyes that encircle the Earth. Horizontally, on Gaea's surface, food, shelter, and clothing remain a major problem for her people due to this perversion of power.

Oikoumenical concerns play a very minor role. Spirituality has been confined to a denominational form of religion that is occupied by the transmittance of dogma and a well defined catechism. For the most part the separation of church and state has left the spiritual domain void. Parochial schools simply stultify it, or reduce it to rules. Perhaps only peace education is examining worldwide notions of how to live together on Gaea's skin. Under its rubric, educators are finding a (re)newed sense of spirituality. Rather than escaping from her pull via the space shuttle or protecting her from nuclear holocaust through the technology of star wars, peace educators have begun a global conversion. In terms of a (re)vivified curriculum, the hope lies that their circumpolar direction can be reintegrated with ecological movements that have similar oikumenical interests. The potential of a new cosmology rests here. 


\section{Speculations of Practice: The Postmodern Spirituality ${ }^{11}$}

The geopolitics of local and global politics are intimately related. The effects of Chernobyl, the burning of the Brazilian rain forests, and the pollution of sulphur dioxide into the air are felt immediately, globally. The local/global dichotomy should become a new ampersand, local\&global. In terms of reversing the binary oppositions, it clearly means supplementing architecture with the notion of dwelling, space with the notion of place (Seamon \& Mugerauer, 1985), and figure with ground both in the literal and figural sense as Mother Earth, Gaea. As opposed to the semiological and poststructuralist musings of so many postmodern theorists, there has been the attempt to reinstate experience and environmental hermeneutics (Mugerauer, 1985) into the architectural discourse in order to recover the lived body. The late philosophical writings of Heidegger, Bachelard, and Merleau-Ponty have been the major influences. ${ }^{12}$ The theorizations of Norbert-Schulz's $(1971,1980)$ are representative of such developments. He has developed the notion of a genius loci, or the "spirit of the place" that is not to be reduced to some identifiable systemic code. Rather, in Alexander's (1979, p. 19) words, it is a "quality without a name." The body is brought back and inhabitation becomes a lived experience (Jager, 1985). As contrasted with the description of a door in semiotic terms (Seligmann, 1982) that relies on the door's meaning as an architectural word in a system of architectural signs, the meaning of door for Lang (1985) is an embodied experience. He speaks of what it is like to experience the threshold that a door provides in the passage of the body from the inside to the outside and vice versa. The description of such lived experience requires great sensitivity. Genius loci becomes an intangible atmosphere that includes the topographical patterns, textures, natural and climatic conditions such as light, wind, and sound. ${ }^{13}$ Regional and local differences are recognized. Buildings and cities are envisioned as living bodies. The word building refers us to the Indo-European base $b h u$, meaning to dwell and is related to the English to be. In phenomenological discourse they are anthropomorphized.

In the broader context, the question becomes How are we to dwell on the planet Earth. The implications for this require that a new cosmology be born and a new relationship with Nature be found. Quite clearly one strand of the search for this new spirituality with Nature has been, and is being, developed by ecofeminists. Freer (1983), provides a summative statement:

Patriarchy has divorced us from the earth and turned our attentions skyward. Modern technology has alienated us from our bodies and made us dependent on machines and chemicals. The Christian church, and other patriarchal religions, viciously suppressed pagan religions and gave us no rites or rituals with which to revere the earth. The gruesome threesome of patriarchy, male religions and technology have dishonored the mother and countenanced the rape and pillage of the planet until she can barely sup- 


\section{University of Alberta}

port life. In the midst of this destruction the children of Gaea are experiencing an immense spiritual hunger, a fearsome dread of isolation and meaninglessness. The tragedy of such inner emptiness is apparent to anyone who has ever experienced, however fleetingly, the celebration which is life. (p. 131)

Together, the implications of this ecofeminist position, Green Party politics (Capra \& Spretnak, 1983) and the movement of women's spirituality (Spretnak, 1982) constitute the major fronts for change in land reform and housing. Ecological groups throughout the world have proposed an entire rethinking of agriculture; they have supported the use of soft energy devices that would harness the sun, wind, and water; they have politically organized themselves to fight for the removal of both nuclear and chemical dump sites; they have tried to remove nuclear weapons (Common Green) and prevented nuclear plants from being built; they have made suggestions for changing public transportation systems and have rethought the whole issue of scale and the human environment (Sale, 1982; Schumacher, 1973; Kumar, 1984, McRobbie, 1981). For feminists, like Merchant (1980), "the death of nature" has meant the loss of organismic metaphors and the mechanization and instrumentalization of medicine through male hands especially in gynecological professions. Her thesis is suggestive of the possible recovery of midwifery and gynecology in women's hands, which of course questions the whole issue of who controls women's bodies. In terms of the question of architecture, the redesigning of hospitals and birth centers might be one direction where her thesis has found fruition (Bishop \& Marks, 1981).

On the whole, ecofeminism and Green Party politics have attempted to deconstruct the binary oppositions between consumption/waste, production/recycling by providing complemen tary solutions. It too is an antihumanistic alternative in the form of its antiprogressive stance. Schumacher's theorizations (1973) in particular have been influential. By introducing eastern ideas, notably Buddhist economics he was able to theorize a way to meet local production needs through the utilization of local resources making economics manageable at the community level. Green Party politics also supports this holistic sense of our embeddedness in nature and the interconnected character of all phenomena, which is parallel to the principles of Native American, pre-Christian European (that is, pagan), Taoist, and Buddhist traditions (Capra \& Spretnak, 1983, p. 54).

The return is to reenchant the world. In Turner's (1969, p. 95) sense, to recover "liminal spaces" that have been lost so that certain spaces take on a symbolic and ritual value, a value different from that of a sports stadium, a movie theater or a mega shopping mall. Argüelles' (1984) Earth Ascending, and LaChapelle's Earth Wisdom (1970), each in its own way, attempt to reenchant geometry. Part of such reenchantment certainly will mean the displacement of vision as the hierarchical sense. 
Paradoxically, we must become blind in order to see again. The use of sound for healing and for having one's being immersed communally has become more and more important as knowledge from oral/aural indigenous cultures are recovered (Schafer, 1985). Since the enlightenment tradition, the dominance of vision as the most objectifying of the senses has locked the human imagination into the metaphors of sight for objective and materialist analysis. The change to aural metaphors suggests the possibility of increasing our sensitivity to the effects of our environment, our buildings, and our furniture on our bodies (Leitner, 1978). It may also be possible to rethink the symbols that have always held us. As Buttimer (1985), arguing for yet another binary complementarity, that of water as against land, writes:

A provocative contrast can be discerned between the Western account of Noah who, after the flood, gathered specimens of all living creatures into the Ark, and the Hindu account of Vishnu, incarnated as a Fish-God, who salvaged specimens of all vegetables and their seeds as well as all animal species. "Since the Fish-God was incarnated in water," a contemporary Hindu scholar writes, "people believe that water is sacred." Might one not speculate that for the Western mind sacredness is symbolized in fixed property (the Ark) whereas for the Hindu it emerges from pilgrimage? On the level of myth, then, two contrasting images of wholeness emerge: one implying home, enclosure, and protection in time and place; the other implying movement, flow, and immersion within the stream of life. (p. 266)

As the integration of Eastern mysticism takes place with Western technology on both sides of the border one can only hope that the emergence of a New Age will recover the best of both worlds. ${ }^{14}$ This surely must lie on the horizon, for postmodernism has brought the globe to a listless state. Given the best possible scenario, one that for the moment closes its eyes to the total annihilation and destruction of Mother Earth through nuclear destruction or greenhouse strangulation, what might the New Age communities be like? Bookchin (1982) speculates that:

The rudiments of an ecological society will probably be structured around the commune-freely created, human in scale, and intimate in its consciously cultivated relationships-rather than clan or tribal forms that are often fairly sizable and anchored in the imperatives of blood and the notion of a common ancestry ... On a still larger scale, the Commune composed of many small communes seems to contain the best features of the polis, without the ethnic parochialism and political exclusivity that contributed so significantly to its decline. Such larger or composite Communes, networked confederally through ecosystems, bioregions, and biomes, must be artistically tailored to their natural surroundings. We can envision that their squares will be interlaced by streams, their places of assembly surrounded by groves, their physical contours respected and tastefully landscaped, their solids nurtured caringly to foster plant variety for ourselves, our domestic animals, and wherever possible the wildlife they may support on their fringes. We can hope that the Communes would aspire to live 


\section{University of Alberta}

with, nourish, and feed upon the life forms that indigenously belong to the ecosystems in which they are integrated. (p. 344)

Currently such cooperative communities as Paolo Soleri's Arcosanti (Arizona), Another Place (New England), Auroville (India), Findhorn (Scotland) are the lone exemplars practicing, however imperfectly, this perceived New World Order values of interconnectedness, redistribution, complementarity, heterarchy, and indeterminacy.

\section{Closing Vignette}

There is certainly a danger of romanticism when speculating about green consciousness and its relationship to esthetics, ethics, politics; the danger is a form of a new biologism, a renewed organicism that, in the past, has been used quite effectively by the Nazi party (Pois, 1986). Today we are seeing an increasing rise of fascist mentality as the purity of nationalism and sovereignty become contentious issues as borders begin to break down and more and more immigrants from impoverished countries flood into the industrialized world. Such fascist mythology has been shaped historically by a male discourse - the pursuit of the Holy Grail (Whitmont, 1982). I am unsure of the full implications of the above proposal, but yet feel somewhat less apprehensive in that it leans heavily toward releasing repressed feminine values so that a dialectical tension and balance between the masculine and feminine principles might be restored. The overcoming of a male psychosis-the contempt for womenrequires a postpatriarchal world that, I believe, is consistent with green poetics. It requires a recasting of what is meant to be a humane being. Perhaps it means a rewriting of the Nietzsche's Dionysian myth, ridding him of his own misogyny so that a fascistic regime will not appropriate his works again, as Whitmont (1982) and Evans (1988) have done. Their proposals seem extreme, yet such visions are required to escape the pull of the male inflated rational ego. Evans has had to rework patriarchal masculinity, while Whitmont has carefully proposed a new theophany.

What has been presented, therefore, is only a hypothesis, an explorative, imaginary representation. Throughout the essay the assumption has always been that the whole enterprise of the Enlightenment has been misguided despite such brilliant social theorists like Habermas (1981) who wish to save it. ${ }^{15}$ The form of rationality and reason that took hold, held the seeds of its own destruction. We are feeling the power of that failed vision in the phallocrats who run the corporations oth today. Our break with nature has dehumanized us, alienated us away from reverence toward a preoccupation with the material because we have overlooked the body and elevated the mind, a direct result of the embourgeoisification of the social order. Understandably, the gender issue haunts this entire attempt to reconstitute our relationship with Nature (Griffin, 1978). 
From where is the politics of this discourse to emerge? The roots of deep ecology and green consciousness draw their strength from altarity, but it is backward looking in its glance, pre-Enlightenment in its dispositionaboriginal, preindustrial, nonurban, native-the primal mind. Here art and society were intimately related and this integration is what has allowed me to identify a possible green poetics. But there is the inevitable danger of believing that we have fallen from grace, kicked out of the proverbial Garden of Eden (Luke, 1988). The haunts of the "noble savage" come to mind, as if there was a pristine time of endless plenitude and innocence. We are fond of pointing to indigenous peoples who have to work little to meet their daily needs, the rest of the time spent in socialization. Such a picture represses the evil side to their cultureracism, slavery, sexism. With no suburbs to escape to, there remains the romantic escape into the past. Likewise, as we look to the East for alternative representations, we decontextualize the very religions we draw from. Is it possible to just extract and incorporate their values without the excessive baggage that comes along with it? No doubt China had the same question when it began to incorporate Western technology. Much of the deep ecological politics falls back to resistance strategies of individual moral choice, reform environmentalism at the local level. It is ecotopian in its view. Yet we live in changed times. It appears that our notions of an avant garde, a small elite that will lead the way, has been misguided. They recapitulate dominance and hierarchy. If esthetics, ethics and politics are to be consonant, then it appears that the personal cannot be separated from the political. Lifestyle, as many feminists claim, must be congruent with one's political style. The Common Green example, as one among many, seems to indicate that the form for change is responsible anarchy, civil (dis)obedience that is sometimes essential (Fromm, 1981). It must occur in uncoerced terms, formed by each body throwing its resistance into the larger whole. Out of ourselves a new visionary myth will be generated. As its articulation unfolds, more and more people(s) will recognize its direction. This is not the life work of a generation, but of many generations. Like the six dimensions that have been outlined, it begins with a journey, a quest towards an unknown vision, yet it is pregnant with insight. Perhaps the child has already been conceived and awaits in the birth canal?

Notes

1. This essay builds on and expands on a previous work, "Toward an Ecological Aesthetic: Notes on a 'Green' Frame of Mind," (Blandy \& Congdon, 1988). The older term "esthetics" rather than "aesthetics" is used throughout to distinguish the former term from its paradigmatic status as part of a philosophical discipline established by Baumgarten in the 18th century. Esthetics will denote the perception of everyday life, whereas aesthetics will be confined strictly to the tradition of fine arts.

2. I take my inspiration from Silverman's (1986) study Inscriptions: Between Phenomenology and Structuralism.

3. Kristeva's writings are important here as someone who has had similar musings in her belief that the pre-Oedipal experiences may be disruptive of the Symbolic Order. 


\section{University of Alberta}

As a seminal work in this regard see Desire in Language (1980) and Powers of Horror (1982). This second book deals with the inadequacies of the first.

4. The import of the word "humane" rather than "human" is used throughout this study to connote a consciousness that will be softer, more compassionate than the one we are living in. The word "human" evokes associations of civilization, the canon founded by males. Although the original word "man" (Mensch) meant "thought," "the one who thinks" or simply "mind," these meanings are associated with male consciousness and need reexamination.

5. The term oikoumenal rather than the more familiar term ecumenical is used to distance this essay from the Christian notion of worldwide values. Oikoumenical values would also be world wide but would go beyond the one identifiable religious tradition. An ecological perspective that treats the Earth as oikos, a home, would be more in keeping with the spirit that lies behind this word.

6. The notion of the visibility of knowledge stems from the Enlightenment tradition that places a high premium on the sense of sight as being the most objectifying of all the senses. See Jay (1986) for an explanation of this claim.

7. I refer to Derrida's responsible anarchy as developed by Caputo (1988).

8. The reader will have noticed that the goddess Gaea is evoked as another name for the Earth. This name is used, following the work of Lovelock (1979), to indicate that the whole Earth is a system and possesses consciousness. This is in direct opposition to the Enlightenment tradition that treated the Earth as dead raw material to be exploited and used for technological gains. Since this system interconnects all "things" through forms of consciousness we have yet to un(cover), it is fitting that the Earth have a name. Gaea is the Greek name for the Mother Earth. She was the oldest of the Divinities. The Olympian gods, under Zeus, took over her ancient shrines, yet they swore oaths by her name since they knew they were subject to her law (Walker, 1983, p. 332).

9. See Megill (1985) and Carroll (1987) for two recent examinations of this antihumanist Nietzschean stance.

10. Sale has dubbed this the Beanstalk principle (1982, p. 59).

11. This comes from Griffin's edited book (1988) by the same name where he charts the emerging spirituality. Spretnak's essay in the same book, for example, presents 10 key green values that are facets of this new spiritualism: ecological wisdom, grassroots democracy, personal and social responsibility, nonviolence, decentralization, community-based economics, postpatriarchal values, respect for diversity, global responsibility, future focus. See also Barbour (1972) for an earlier attempt.

12. Especially Heidegger's essay "Building Dwelling Thinking," in Poetry, Language, Thought (1971); Bachelard's (1964) Poetics of Space (1964); and Merleau-Ponty's (1962) The Phenomenology of Perception.

13. A well developed example of this approach is provided by Violich's (1985) intuitive "reading" of four Dalmatian towns and Brenneman's (1985) description of the loric and sacred spaces in the holy wells of Ireland.

14. An integration of sorts has already taken place in the New Age science. To mention but a few: Sheldrake's (1982) development of morphogenetic fields in biology; the whole development of the chaos theory (Gleick, 1987); Prigogine's (1980) work on dissipative structure, Mandelbrot's (1977) mathematical studies of the irregular patterns of nature; and, of course, the whole development of microphysics that has become a recent playground of metaphysical thought (see Briggs \& Peat, 1984).

15. Habermas (1981) and perhaps Blumenberg (1983) represent the more persuasive attempts today to totalize history and provide a grand theory in the tradition of Marx and Hegel. Other historians, notably French poststructuralists like Foucault and Derrida, think this is an absurd task. From the standpoint of this essay, a fundamental rethinking of eschatology would need to begin with the reexamination of patriarchy in the spirit of Lerner's (1986) and Whitmont's (1982) historical reformulations since our spiritual discourse has been shaped by male patriarchs. Goldenberg (1982) and Daly (1978) have made such a critique of the Judeo-Christian 


\section{0th Anniversary of the Faculty of Education}

religious tradition from a feminist viewpoint. They argue that this tradition should be replaced. Other feminists, like Fiorenza (1985) argue that the Judeo-Christian tradition, once reformed, may still be able to speak to women today. For the purposes of this argument, the aesthetic roots to Nature belong to a pagan era, prior to the Chalcolithic or Copper period. An exploration of pagan spirituality, as developed during the so-called "magical" phase of human consciousness (Gebser, 1985), is in order. This seems justified on the grounds that no afterlife conceptualizations had been spawned. These came with male sun religions. In the Egyptian context, for example, only the pharaoh had a $k a$ and a privileged life after death, whereas in pagan religions, like the ancient Japanese religion of Shinto, there was no striving for a life after death. Yet these animistic religions have a great reverence for Nature. All deeds are to be done in the present so that nature could be revered.

\section{References}

Alexander, C. (1979). The timeless way of the building. New York: Oxford University Press.

Argüelles, J. (1984). Earth ascending: An illustrated treatise on the law governing whole systems. Boulder, $\mathrm{CO}$ and London: Shambhala.

Attali, J. (1985). Noise: The political economy of music (B. Massumi, Trans.). Minneapolis: University of Minnesota Press (originally published in 1977).

Bachelard, G. (1964). Poetics of space (M. Jolas, Trans.). Boston: Beacon Press.

Barbour, I.G. (Ed.). (1972). Earth might be fair: Reflections on ethics, religion, and ecology. Englewood Cliffs, NJ: Prentice-Hall.

Baudrillard, J. (1981). For a critique of the political economy of the sign (Charles Levin, Trans.). St. Louis, MO: Telos Press.

Baudrillard, J. (1983). Simulations (P. Foss, P. Patton, \& P. Beitchman, Trans.). New York: Semiotext(e).

Berman, M. (1981). The re-enchantment of the world. Ithaca, NY: Cornell University Press.

Bishop, J., \& Marks, B. (1981). A place of birth: The changing structure of obstetrical care. Heresies, $3(11)$, 48-50.

Blumenberg, H. (1983). The legitimation of the modern age. Cambridge, MA: MIT Press.

Bookchin, M. (1981). The ecology of freedom. Palo Alto, CA: Cheshire.

Boulding, E. (1976). The underside of history. Boulder, CO: Westview Press.

Brenneman, W. Jr. (1985). The circle and the Cross: Loric and sacred space in the holy wells of Ireland. In D. Seamon \& R. Mugerauer (Eds.), Dwelling, place and environment: Towands a phenomenology of person and world (pp. 137-158). Dordrecht, Boston, Lancaster: Nijhoff.

Briggs, J.P., \& Peat, D.F. (1984). Looking glass universe: The emerging science of wholeness. New York: Simon \& Schuster.

Bürger, C. (1985, Summer). The reality of "machines": Notes on the rhizome-thinking of Deleuze and Guattari. Telos, 64, 33-44.

Buttimer, A. (1985). Nature, water symbols and the human quest for wholeness. In D. Seamon \& R. Mugerauer (Eds.), Dwelling, place and environment: Towards a phenomenology of person and world (pp. 257-280). Dordrecht, Boston, Lancaster: Nijhoff.

Capra, F., \& Spretnak, C. (1983). Green politics. New York: Dutton.

Caputo, J.D. (1987). Radical hermeneutics: Repetition, deconstruction and the hermeneutic project. Bloomington and Indianapolis, IN: Indiana University Press.

Caputo, J.D. (1988). Beyond aestheticism: Derrida's responsible anarchy. Research in Phenomenology, XVIII, 59-73.

Carroll, D. (1987). Paraesthetics: Foucault, Lyotard, Derrida. New York and London: Methuen.

Castoriadis, C. (1984). The imaginary institution of society. In J. Fekete (Ed.), The structural allegory: Reconstructive encounters with the new French thought (pp. 6-45). Minneapolis, MN: University of Minnesota Press. 


\section{University of Alberta}

Chatwin, B. (1987). The songlines. London: Jonathan Cape.

Collins, J. (1989). Uncommon cultures: Popular culture and post-modernism. New York and London: Routledge.

Connor, S. (1989). Postmodern culture: An introduction to theories of the contemporary. Oxford: Blackwell.

Daly, M. (1978). Beyond God the Father: Towards a philosophy of women's liberation. Boston: Beacon Press.

Deleuze, G., \& Guattari, F. (1983). Anti-Oedipus: Capitalism and schizophrenia (R. Hurley, M. Seem, \& H. Lane, Trans.). Minneapolis, MN: University of Minnesota Press.

Devall, B. (1979). Ecological consciousness and ecological resisting: Guidelines for comprehension and research. Humboldt Journal of Social Relations, 9, 177-196.

Devall, B. (1980). The deep ecology movement. Natural Resources Journal, 20, 295-322.

Devall, B. (1984). The development of nature resources and the integrity of nature. Environmental Ethics, 6, 293-323.

Devall, B., \& Sessions, G. (1985). Deep ecology. Layton, UT: Peregrine Smith.

Derrida, J. (1974). Of grammatology (G.C. Spivak, Trans.). Baltimore, MD: Johns Hopkins University Press.

Drengson, A.R. (1983). Shifting paradigms: From technocrat to planetary person. Victoria, BC: Light Star Press.

Dreyfus, L.H., \& Rabinow, P. (1982). Michel Foucault: Beyond structuralism and hermeneutics (2nd ed.). Chicago: University of Chicago Press.

Elshtain, J.B. (1981). Public man, private woman. Princeton, NJ: Princeton University Press.

Evans, A. (1988). The god of ecstacy: Sex roles and the madness of Dionysus. New York: St. Martin's Press.

Felski, R. (1989). Beyond feminist aesthetics: Feminist literature and social change. Cambridge, MA: Harvard University Press.

Ferguson, M. (1980). The aquarian conspiracy: Personal and social transformation in the 1980s. Los Angeles, CA: Tarcher.

Fiorenza, E.S. (1985). In memory of her: A feminist theological reconstruction of Christian origins. New York: Crossroad.

Foucault, M. (1972). The archeology of knowledge (A.M. Sheridan Smith, Trans.). New York: Pantheon.

Foucault, M. (1984). What is an author? In P. Rabinow (Ed.), The Foucault reader (pp. 101-120). New York: Pantheon.

Freer, J. (1983). Gaea: The earth as our spiritual heritage. In L. Caldecott \& S. Leland (Eds.), Reclaim the earth: Women speak for our life on earth (pp. 131-135). London: Women's Press.

Fromm, E. (1981). On disobedience and other Essays. New York: Seabury Press.

Gadamer, H.-G. (1975). Truth and method (G. Barden \& J. Cumming, Trans.). London: Sheed \& Ward.

Gebser, J. (1985). The ever-present origin (N. Barstad \& A. Mickunas, Trans.). Athens $\mathrm{OH}$ : Ohio University Press.

Gleick, J. (1987). Chaos: Making of a new science. Penguin.

Goffman, E. (1961). Asylums: Essays on the social situation of mental patients and other inmates. Garden City, NY: Anchor.

Goldenberg, N. (1982). The end of God. Ottawa: University of Ottawa Press.

Gramsci, A. (1971). Selections from the prison notebooks (Q. Hoare \& G. Smith, Eds. \& Trans.). New York: International Publishers.

Griffin, S. (1978). Woman and nature: The roaring inside her. New York: Harper \& Row.

Griffin, D.R. (Ed.). (1988). Spirituality and society: Postmodern visions. New York: State University of New York Press.

Habermas, J. (1981, Winter). Modernity versus postmodernity. New German critique, 22, 15-18.

Heidegger, M. (1962). Being and time (J. Macquarrie \& E. Robinson, Trans.) New York: Harper \& Row. 
Heidegger, M. (1971). Building dwelling thinking. In A. Hofstadter (Trans.), Poetry, language, thought (pp. 145-161) New York: Harper \& Row.

Highwater, J. (1981). The primal mind: Vision and reality in Indian America. New York: Harper \& Row.

Hillman, J. (1975). Re-visioning psychology. New York: Harper \& Row.

Huyghe, R. (1977). Color and the expression of interior time in Western art. In Color symbolism: Six excerpts from the Eranos yearbook 1972 (pp. 129-166). Dallas, TX: Spring.

Jager, B. (1985). Body, house and city: The intertwinings of embodiment, inhabitation and civilization. In D. Seamon \& R. Mugerauer (Eds.), Dwelling, place and environment: Towards a phenomenology of person and world (pp. 215-226).

Dordrecht, Boston, Lancaster: Nijhoff.

jagodzinski, j. (1988). Toward an ecological aesthetic: Notes on a "green" frame of mind. In D. Blandy \& K.G. Congdon (Eds.), Art in a democracy (pp. 138-164). New York: Teachers College Press.

Jameson, F. (1983). Postmodernism and consumer society. In H. Foster (Ed.), Anti-aesthetic: Essays on postmodern culture (pp. 111-125). Port Townsend, WA: Bay Press.

Jameson, F. (1984, July-August). Postmodernism, or the cultural logic of late capitalism. New Left Review, 146, 53-93.

Jaspers, K. (1957). Man in the modern age (E. Paul \& C. Paul, Trans). New York: Doubleday.

Jay, M. (1986). In the empire of the gaze: Foucault and the denigration of vision in twentieth-century thought. In D.C. Hoy (Ed.), Foucault: A critical reader (pp. 175-204). Oxford: Blackwell.

Jaynes, J. (1976). The origins of consciousness in the breakdown of the bicameral mind. Toronto, ON: University of Toronto Press.

Jencks, C. (1973). Adhocism: The case for improvisation. New York: Doubleday-Anchor. Kandinsky, W. (1977). Concerning the spiritual in art. New York: Dover.

Kristeva, J. (1980). Desire in language: A semiotic approach to literature and art (L.S. Roudiez, Ed., T. Gora, A. Jardine, \& L.S. Roudiez, Trans.). New York: Columbia University Press.

Kristeva, J. (1982). Powers of horror: An essay on abjection (L.S. Roudiez, Trans.). New York: Columbia University Press.

Kumar, S. (Ed.). (1984). The Schumacher lectures Volume II. London: Bond \& Briggs.

LaChapelle, D. (1970). Earth wisdom. Silverton, CO: Finn Hill Arts.

Lang, R. (1985). The dwelling door: Towards a phenomenology of transition. In D. Seamon \& R. Mugerauer (Eds.), Dwelling, place and environment: Towards a phenomenology of person and world (pp. 201-214). Dordrecht, Boston, Lancaster: Nijhoff.

Leitner, B. (1978). Ton: Raum/Sound: Space. New York: New York University Press. Lerner, G. (1986). The origins of patriarchy. Oxford: Oxford University Press.

Levin, D.M. (1985). The body's recollection of being: Phenomenological psychology and the deconstruction of nihilism. London, Boston, Melbourne, and Henley: Routledge \& Kegan Paul.

Lovelock, J.E. (1979). Gaia: A new look at life on earth. Oxford: Oxford University Press. Luke, T, (1988, Summer). The dreams of deep ecology. Telos, 76, 65-92.

Lyotard, F.J. (1984). The postmodern condition: A report on knowledge (G. Bennington \& B. Massumi, Trans.). Minneapolis, MN: University of Minnesota Press.

Mandelbrot, B. (1977). The fractal geometry of nature. New York: Freeman.

May, R. (1975). The courage to create. New York: Norton.

McClary, S. (1985). Afterword: The politics of silence and sound. In J. Attali (Ed.), Noise: The political economy of music (B. Massumi, Trans., pp. 149-160). Minneapolis, MN: University of Minnesota Press.

McRobbie, G. (1981). Small is possible. New York: Harper \& Row.

Megill, A. (1985). Prophets of extremity: Nietzsche, Heidegger, Foucault, Derrida. Berkeley, CA: University of California Press. 


\section{University of Alberta}

Merchant, C. (1980). The death of nature: Woman, ecology, and the scientific revolution. San Francisco CA: Harper \& Row.

Merleau-Ponty, M. (1962). The phenomenology of penception (Colin Smith, Trans.). New York: Humanities Press.

Mugerauer, R. (1985). Language and environment. In D. Seamon \& R. Mugerauer (Eds.), Dwelling, place and environment: Towards a phenomenology of person and world (pp. 51-70). Dordrecht, Boston, Lancaster: Nijhoff.

Naess, A. (1973). The shallow and deep, long-range ecology movement: A summary. Inquiry, 16, 95-100.

Naess, A. (1984). Intuition, intrinsic value and deep Ecology. The Ecologist, 14, 210-214.

Norbert-Schulz, C. (1971). Existence, space and architecture. New York: Praeger.

Norbert-Schulz, C. (1980). Genius loci: Towards a phenomenology of anchitecture. New York: Rizzoli.

Papanek, V. (1974). Design for the real world. New York: Granada.

Phillips, J.A. (1984). Eve: The history of an idea. San Francisco, CA: Harper \& Row.

Pois, R.A. (1986). National socialism and the religion of nature. New York: St. Martin's Press.

Porritt, J. (1984). Seeing green: The politics of ecology explained. Oxford: Blackwell.

Prigogine, I. (1980). From being to becoming: Time and complexity in the physical sciences. San Francisco, CA: Freeman.

Rifkin, J. (1984). Algeny: A new word-A new world. Harmondsworth, UK: Penguin.

Rossbach, S. (1983). Feng shui: The Chinese art of placement. New York: Dutton.

Ruether, R.R. (1983). Sexism and god-talk: Toward a feminist theology. Boston: Beacon

Said, E. (1978). Orientalism. New York: Vintage Press.

Sale, K. (1982). Human Scale. New York: Perigre Books; Toronto, ON: General

Sale, K. (1984). Mother of all. In S. Kumar (Ed.), Schumacher lectures, Volume II (pp. 219-250). London: Blond \& Briggs.

Sale, K. (1985). Dwellers in the land: The bioregional vision. San Francisco, CA: Sierra

Satin, M. (1978). New age politics: Healing, self and society Vancouver, BC: White Cap

Schafer, M. (1985). Acoustic pace. In D. Seamon \& R. Mugerauer (Eds.), Dwelling, place

and environment: Towards a phenomenology of person and world (pp. 87-98).

Dordrecht, Boston, Lancaster: Nijhoff.

Schumacher, E.F. (1973). Small is beautiful: A study of economics as if people mattered.

London: Briggs \& Briggs.

Schumacher, E.F. (1979). Good work. New York: Harper \& Row.

Seamon, D., \& Mugerauer, R. (Eds.). (1985). Dwelling, place and environment: Towards a phenomenology of person and world. Dordrecht, Boston, Lancaster: Nijhoff.

Segall, M.H., Campbell, D.T., \& Herkovitz, J.J. (1966). The influence of culture on visual perception. New York: Bobbs-Merrill.

Semiotica, 38(1/2), 55-76.

Sessions, G. (1987). The deep ecology movement. Environmental Review, VII, 105-126

Sheldrake, R. (1981). A new science of life: The hypothesis of formative causation.

London: Granada.

Silverman, K. (1986). Fragments of a fashionable discourse. In T. Modleski (Ed.), Studies

in entertainment: Critical approaches to mass culture (pp.155-166). Bloomington and

Indianapolis, IN: Indiana University Press.

Silverman, H.J. (1987). Inscriptions: Between phenomenology and structuralism. New

York and London: Routledge \& Kegan Paul.

Snyder, G. (1974). Turtle Island. New York: New Directions.

Spretnak, C. (Ed.). (1982). The politics of women's spirituality: Essays on the rise of

spiritual power within the feminist movement. Garden City, NY: Anchor
Press/Doubleday. 


\section{0th Anniversary of the Faculty of Education}

Spretnak, C. (1988). Postmodern directions. In D.R. Griffin (Ed.), Spirituality and society: Postmodern visions (pp. 33-40). New York: State University of New York Press.

Stravrianos, L.S. (1976). The promise of the coming dark age. San Francisco, CA: Freeman.

Tobias, M. (Ed.). (1985). Deep ecology. San Diego, CA: Avant.

Turner, V. (1969). The ritual process structure and anti-structure. Chicago: Aldine.

Violich, F. (1985). Towards revealing the sense of place: An intuitive "reading" of four Dalmatian towns. In D. Seamon \& R. Mugerauer Dwelling, place and environment: Towards a phenomenology of person and world (pp. 113-136). Dordrecht, Boston, Lancaster: Nijhoff.

Von Franz, M.L. (1978). Interpretation of fairytales. Irving, TX: Spring.

Walker, B.G. (1983). The woman's encyclopedia of myths and secrets. San Francisco, CA: Harper \& Row.

Whitmont, E. (1982). The return of the goddess. New York: Crossroad.

Winnicott, D.W. (1971). Playing and reality. London: Tavistock. 